\title{
ACQUISITION OF FOREIGN CITIZENSHIP BY MOLDOVAN IMMIGRANTS
}

\author{
Tatiana TABAC ${ }^{1}$, PhD Student, \\ National Institute for Economic Research, Republic of Moldova
}

\author{
DOI: https://doi.org/10.36004/nier.es.2019.2-09 \\ JEL Classification: F22, K37, J11 \\ UDC: $314.74,325.14$
}

\section{ABSTRACT}

The paper explores some aspects of the acquisition of foreign citizenship by immigrants from Moldova. The purpose of the study is to estimate the size and geography of acquisition of foreign citizenship in context of migration policies changes in countries of destination. The study is based on statistical analysis of the OECD, Eurostat database and other representative sources, as well as an analysis of migration policy of the countries of citizenship acquisition. The results show that about a million people received foreign citizenship from 1992 up to present. The main countries for acquiring citizenship are: Romania, Russia, USA, Portugal, Italy, Bulgaria, Canada and Germany. The access of Moldova population to citizenship of developed countries contributes to the intensification and expansion of international migration. For Moldovan immigrants, the policies of the countries of destination have an important role in the process of acquiring citizenship.

Keywords: naturalization, foreign citizenship, Moldovan immigrants, migration policy.

In articol se discută unele aspecte privind dobândirea cetățeniei străine de către imigranții din Moldova. Scopul cercetării constă în estimarea dimensiunii și geografiei dobândirii cetăteniei străine prin prisma schimbărilor în politicile migraționale din țările de destinație. Studiul se bazează pe analiza statistică a bazei de date OCDE, Eurostat și a altor surse reprezentative, precum și analiza politicilor migraționale ale țărilor de dobândire a cetățeniei. Rezultatele studiului arată că aproximativ un milion de persoane au primit cetățenia străină din 1992 până în prezent. Principalele țări de dobândire a cetățeniei sunt: România, Rusia, SUA, Portugalia, Italia, Bulgaria, Canada și Germania. Accesul populației Moldovei la cetățenia țărilor dezvoltate contribuie la intensificarea și extinderea migrației internaționale. Pentru imigranții din Moldova, politicile țărilor de destinație au un rol important în procesul de dobândire a cetățeniei.

Cuvinte-cheie: naturalizare, cetățenie străină, imigranți din Moldova, politici migraționale.

В статье рассматриваются некоторые аспекты приобретения иностранного гражданства иммигрантами из Молдовы. Цель исследования: оценка масштабов и географии приобретения иностранного гражданство в контексте изменений миграционной политики в странах назначения. Исследование основано на статистическом анализе базы данных ОЭСР, Евростата и других репрезентативных источников, а также анализе миграционной политики стран приобретения гражданства. Результаты исследования показывают, что около миллиона человек получили иностранное гражданство с 1992 г. по настоящее время. Главными странами приобретения гражданства являются: Румыния, Россия, США, Португалия, Италия, Болгария, Канада и Германия. Доступ населения Молдовы к гражданству развитых стран способствует интенсификации и расширению международной миграции. Для иммигрантов из Молдовы политика стран назначения играет важную роль в процессе получения гражданство.

Ключевые слова: натурализация, иностранное гражданство, мигранты из Молдовы, миграционная политика.

INTRODUCTION. There are already three decades since international migration became a massive phenomenon for the Republic of Moldova. The last censuses in the destination countries (2011) registered about 600 thousand migrants from Moldova with residence abroad (15, GAGAUZ, 
O., et al. 2016), this number representing about $20 \%$ of the total population. According to recent estimates, Moldova is one of the countries with highest emigration rates in the European area (13, European Demographic Data Sheet, 2018). In some countries, duration of stay of immigrants exceeds 10-20 years (e.g. Germany, Russia, Italy, Portugal, USA), meaning that for many immigrants the host country has become the country of permanent residence. In Russia, Germany (28, TABAC, T., 2017) and Italy (9, DELEU, E., 2017) second-generation immigrants were registered already. The analysis of citizenship and its acquisition by Moldovan immigrants is necessary, on the one hand as part of studying their integration in destination countries, and on the other hand as an important factor contributing to the expansion of international migration. For Moldovan immigrants, acquiring the citizenship of one of the EU countries represents firstly free movement and the right to work in almost all countries worldwide, and secondly a wider range of opportunities for settlement migration for people who aspire to do so. In this context, in recent decades, access to Romanian citizenship is an important factor that favors legal migration. The purpose of the research is to estimate the size and geography of acquisition of foreign citizenship during the 1992-2016 period, according to the countries which conferred them and naturalization policies that favored this. To our best knowledge, there aren't any studies that approach the naturalization process and acquisition of foreign citizenship by Moldova population. Therefore, the importance of our study is determined by supplementing this gap, as well as by contributing to the development of migration policies.

\section{UNDERSTANDING NATURALIZATION DECISIONS}

There are numerous research papers that study the determinants, causes, barriers and consequences of the immigrants naturalisation in destination countries. All of these studies are conducted to understand why some immigrants are more likely than others to become naturalized. Regardless of the country and promoted policies, most research shows that only a fraction of the eligible immigrants access the citizenship of the host country (22, Mazzolari, 2009; DeVoretz and Pivnenko, 2005).

In literature we find various factors that determine an immigrant to access the citizenship of the country in which he/she lives. Some studies emphasize the importance of the individual characteristics of immigrants such as demographic characteristics (4, BEVELANDER, P., VEENMAN, J. 2006), economic characteristics- income, occupation and education (7, CHISWICK, B.R., MILLER, P.W., 2008; 12, DEVORETZ, D.J., PIVNENKO, S., 2005), period of immigration or residence (30, TRAN, K., KUSTEC, S., CHUI, T., 2005), cultural background. In other studies, the focus is on the political and institutional context of country of immigration as a factor that also influences the naturalization process (32, VINK, M.P., PROKIC-BREUER, T., DRONKERS, J., 2013; 33, VINK, M.P., DRONKERS, J., 2012). In addition, some studies show that the characteristics of the origin country influence the naturalization process in destination countries, particularly regarding the possibility to hold dual citizenship (34, YANG, P.Q., 1994; 7, CHISWICK, B.R., MILLER, P.W., 2008, 19, JONES-CORREA, M., 2001), although not as much as individual characteristics. In this aspect it has been demonstrated that immigrants from developing countries have higher naturalization rates, than immigrants from developed countries (7, CHISWICK, B.R., MILLER, P.W., 2008; 31, VINK, M.P., PROKIC-BREUER, T., DRONKERS, J., 2017).

An important barrier in the naturalization process is the possibility to hold double citizenship, granting the right of migrants to become naturalized in the receiving country without losing the nationality of the country of origin. Though, many countries have already legalized dual citizenship, there are countries in the world that do not accept it, as well as countries that impose restrictions on acquisition, many of which are located in Europe. Prohibition on dual citizenship affects especially immigrants from developed countries, who have more to lose if they break the legal connection with the country of birth (32, VINK, M.P., PROKIC-BREUER, T., DRONKERS, J., 2013). In this sense, the researchers consider that losing the citizenship of country of origin is the main cost of naturalization (2, BEVELANDER, P., 2010).

At the same time, the existence of other important barriers in the naturalization process was demonstrated, as a good knowledge of the language, the difficulty of the citizenship test, the physical presence in the country, but also the financial barriers, as well as the high cost of documents 
processing. For example, Hainmueller et al. $(18,2018)$ have shown that administrative taxes are a barrier for low income immigrants who want to become US citizens.

However, acquiring the citizenship of destination country offers more benefits to immigrants, but first represents the people's intention to permanently settle in the country. Most often it is considered that the benefits of naturalization are the equal rights with citizens of destination country, the right to vote and political participation (10, DEROOIJ, E.A., 2011), greater insurance and protection from the state, the chance of being employed in public and governmental positions, the opportunity to increase the income and to obtain higher professional positions (Liebig and Von Haaren 2011), to buy or to rent a house (2, BEVELANDER, P., 2010), as well as more access to bank loans (14, ENCHAUTEQUI, M.E., GIANNARELLI, L., 2015). For citizens of developing countries, the citizenship of a developed country is a benefit to travel without barriers at international level (14, ENCHAUTEQUI, M.E., GIANNARELLI, L., 2015; 33, VINK, M.P., DRONKERS, J., 2012). At the same time, refugees, asylum seekers and persecuted people in their country of origin will be more motivated to become naturalized in the host country (3, BEVELANDER, P., DEVORETZ, D.J., 2008).

From all the benefits obtained from naturalization the most attention is on the economic impact of naturalization. Lots of studies both at European, and global level shows how important is the economic effect for naturalized immigrants. We find a positive relationship in this regard to Bratsberg, Ragan Jr., and Nasir (6, 2002), DeVoretz and Pivnenko (12, 2005), Steinhardt and Wedemeier $(26,2011)$, Picot and Hou $(23,2011)$. It has been found for the US that naturalization can increase the earnings of eligible immigrants with 8,9\% (14, ENCHAUTEQUI, M.E., GIANNARELLI, L. 2015), and according to the estimates of DeVoretz and Pivnenko $(11,2008)$, naturalized immigrants have the incomes with 3.5\% higher than non-citizens if they are from an OECD country and with $14.6 \%$ if they are from outside OECD.

Acquizition the citizenship of country of immigration represents a process that requires applicants to demonstrate language and historical-cultural knowledge, financial independence, adequate civic behaviour, or in other words, to show evidence of social integration. For this reason obtaining citizenship is considered the coronation of a completed integration process $(1$, BAUBOCK, R. et al., 2006).

\section{DATA AND METHODS}

For analysis, we used the data on the acquisition of nationality provided by OECD and Eurostat. For Russia, we used the data provided by Minister of the Interior/ Federal Migration Service and presented by Čûdinovskih, O.S. $(8,2018)$. To study worldwide policies, we used World Population Policies Database by UN DESA, and EUDO Citizenship Observatory database for national level policies. The study is based on statistical data analysis and policies analysis.

World experience in acquiring foreign citizenship

There are two main ways of acquiring citizenship at birth: jus sanguinis, it offers nationality right only to persons with the same racial, linguistic, ethnic and cultural characteristics of titular nation and jus soli, which establishes citizenship right whether or not the person corresponds to the mentioned characteristics. J.B. Scott records in 1930 that in 17 countries in Europe, jus sanguinis is the only nationality test, while in America most states use a combination of these two paths. In the long run, many European countries adopted jus soli criterion (recently Germany and Greece) and today we know a more frequent coexistence of these two criteria (17, GUIMEZANES, N., 2011).

Naturalization is another way of acquiring citizenship and it is used by people who don't have jus sanguinis or jus soli connection with the country. Naturalization is the process by which a foreign citizen can acquire, under the law conditions, the citizenship of country of resident. At present, naturalization is recognized and used worldwide, except some countries from Asia and Oceania (Lebanon, Kuwait, United Arab Emirates, Myanmar, Nauru) (Fig.2). At the same time, a large number of countries restrict acquisition of citizenship through naturalization. These are European countries such as Spain, Italy, Switzerland, Austria, Slovenia, Lithuania and the Republic of Moldova (Fig. 1), India and Nepal from Asia, Brazil and Venezuela from South America, as well as an important part of African countries. Typically, naturalization is a voluntary action of applicant and requires that certain specific conditions to be met. Each country has adopted own requirements for naturalization. 


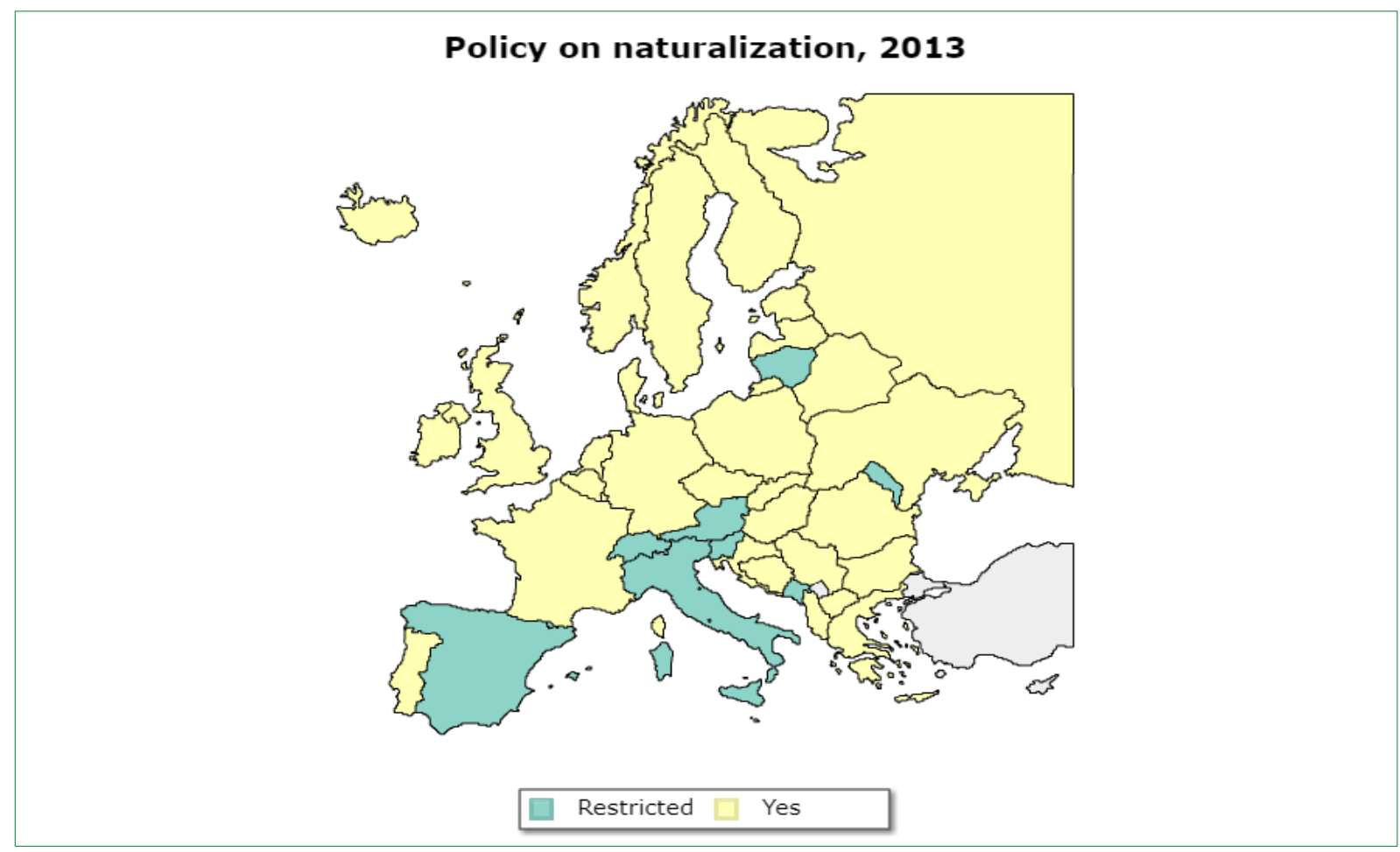

Figure 1. Policy on naturalization in Europe, 2013

Source: The figures were elaborated by the author based on the database UN DESA World Population Policies Database (https://esa.un.org/PopPolicy/about_database.aspx, accessed 10.05.2019)

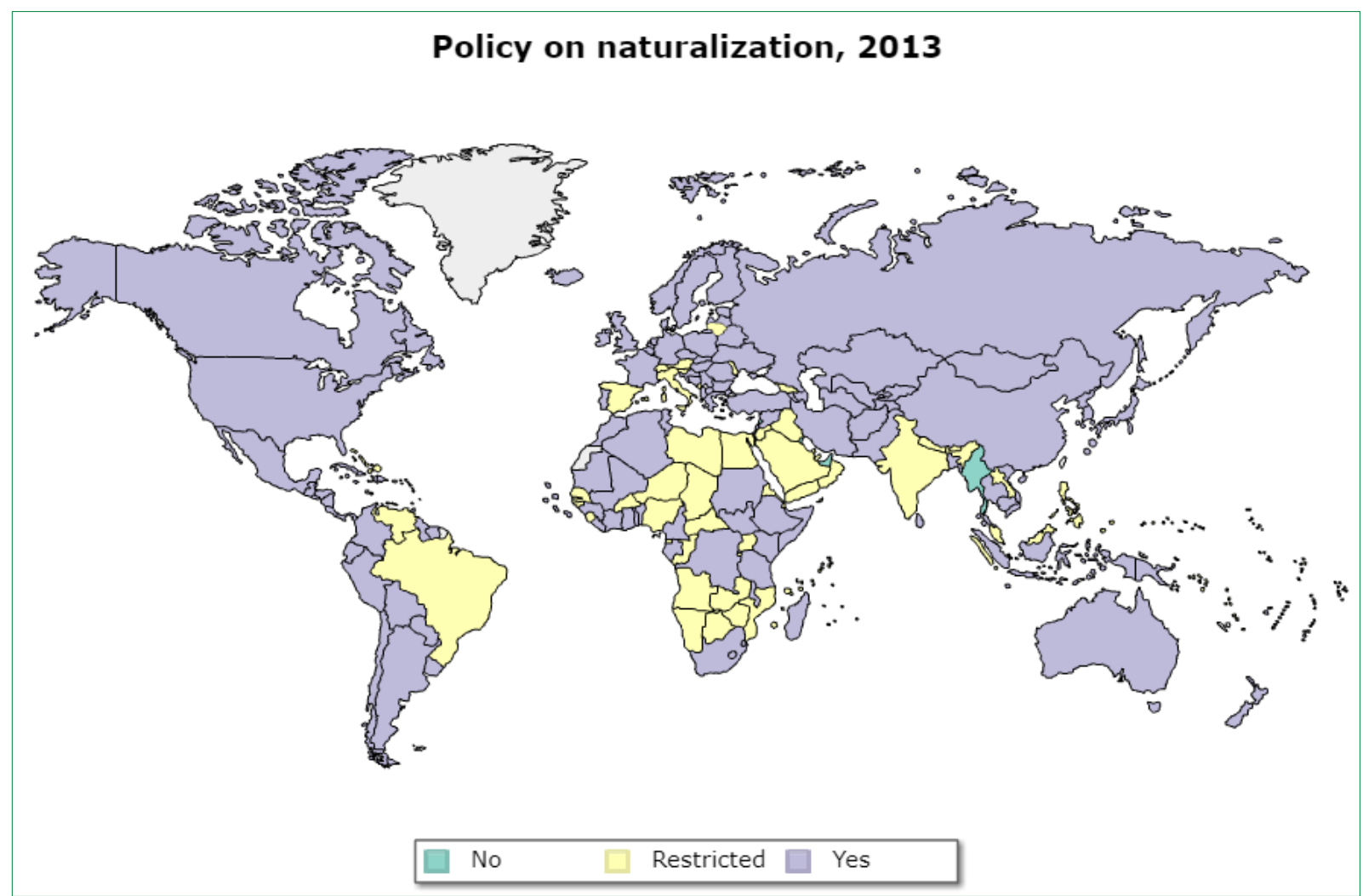

Figure 2. Policy on naturalization in World, 2013

Source: the figures were elaborated by the author based on the database UN DESA World Population Policies Database (https://esa.un.org/PopPolicy/about_database.aspx, accessed 10.05.2019) 
According to OECD International Migration Database, the number of persons who acquired citizenship in a foreign country over the past 30 years (1987-2016) amounts to 43.5 million. In 2008, for the first time, 2 million people were registered in OECD, and for the second time, 1 million people in USA, the first case being recorded in 1996. Data for 2013-2016 shows that 2 million persons annually acquired citizenship in other countries. The most cases were registered in USA $17.3 \mathrm{mln}(40 \%)$, Canada - $4.5 \mathrm{mln}(10 \%)$, UK and Australia, $3.2 \mathrm{mln}(7 \%)$ and $3.1 \mathrm{mln}(7 \%)$, in France and Germany - $2.8 \mathrm{mln}(6.5 \%)$ and $2.6 \mathrm{mln}(6 \%)$, Spain $-1.4 \mathrm{mln}$ and Italy $-1.2 \mathrm{mln}$, in Sweden and Netherlands - $1.0 \mathrm{mln}$ each, in Belgium $0.9 \mathrm{mln}$, Switzerland - $0.8 \mathrm{mln}$, New Zeeland and Austria - $0.5 \mathrm{mln}$ each.

There are significant regional differences in immigrants access rate to citizenship of the host country. It was estimated that about $80 \%$ of foreign population of Australia, Sweden and the Netherlands is naturalized after ten years of residence, in Canada - 89\%, Norway and UK - around 70\%, USA, Austria and Denmark - 50-60\%, France - 47\%, Switzerland and Germany - 35\% and $37 \%$, Luxembourg with only $12 \%$ (21, LIEBIG, T., VON HAAREN, F., 2011). In this context, it seems that Europe is differentiated by lower rates of naturalization compared to other economic developed countries. There are important scientific debates to understand whether these differences are due to individual characteristics of immigrants or policies adopted in destination and origin countries. Many studies have shown the importance of preserving the nationality of country of origin.

Dual citizenship. The opportunity to hold the citizenship of two countries at the same time is relatively recent. Human history reminds us that in the not-so-distant past, dual citizenship has been banned in most states of the world. In this regard, the Hague Convention of April 12, 1930, agrees that each person must have one citizenship and only one citizenship, and cases of statelessness and dual citizenship should be avoided. A large number of countries have revised their nationality laws in accordance with this Convention, most of them from the post-war era, including the USSR.

After the World War, on May 6, 1963, the Council of Europe adopted the Convention on the Reduction of Cases of Multiple Nationality and on Military Obligations in Cases of Multiple Nationality according to which nationals who have reached the age of majority and who acquire by their own will, through naturalization or recovery, the citizenship of another country cannot retain their citizenship. Also a person possessing the citizenship of two or more countries must renounce them with the consent of the part to which wishes to renounce.

From November 6, 1997, the Council of Europe adopts a new European Convention on Citizenship in which it is stipulated that each State is free to decide what consequences to assign if its citizens acquire or hold the citizenship of another country. In this way, the Council of Europe aims to achieve greater unity among its members and to avoid any form of discrimination on the grounds of citizenship by sex, religion, race, color, national or ethnic origin. In essence, this new convention agrees with dual citizenship.

Governments survey on World Population Policies conducted by UN DESA shows which governments allow their citizens to retain citizenship when acquiring another one, and if so, under what conditions or restrictions. Restrictions refer to: (i) the involved countries (accepting dual citizenship in the case of certain countries) or (ii) the rights involved (accepting dual citizenship with restrictions on full citizenship rights). The results are presented in Figures 3 and 4.

If we look at the situation in Europe in 2013, we notice that most states accept dual citizenship without any restrictions, only some countries, as the Netherlands, Austria, Germany, Czech Republic, Denmark, Norway, Spain, Poland, Belarus and Lithuania recognize dual citizenship with restrictions. Only three post-Soviet countries do not accept dual citizenship: Ukraine, Latvia and Estonia. Researching the situation in the world we find that most countries in the world have accepted dual citizenship without restrictions. Most states that do not recognize dual citizenship are from Asia and Africa. 


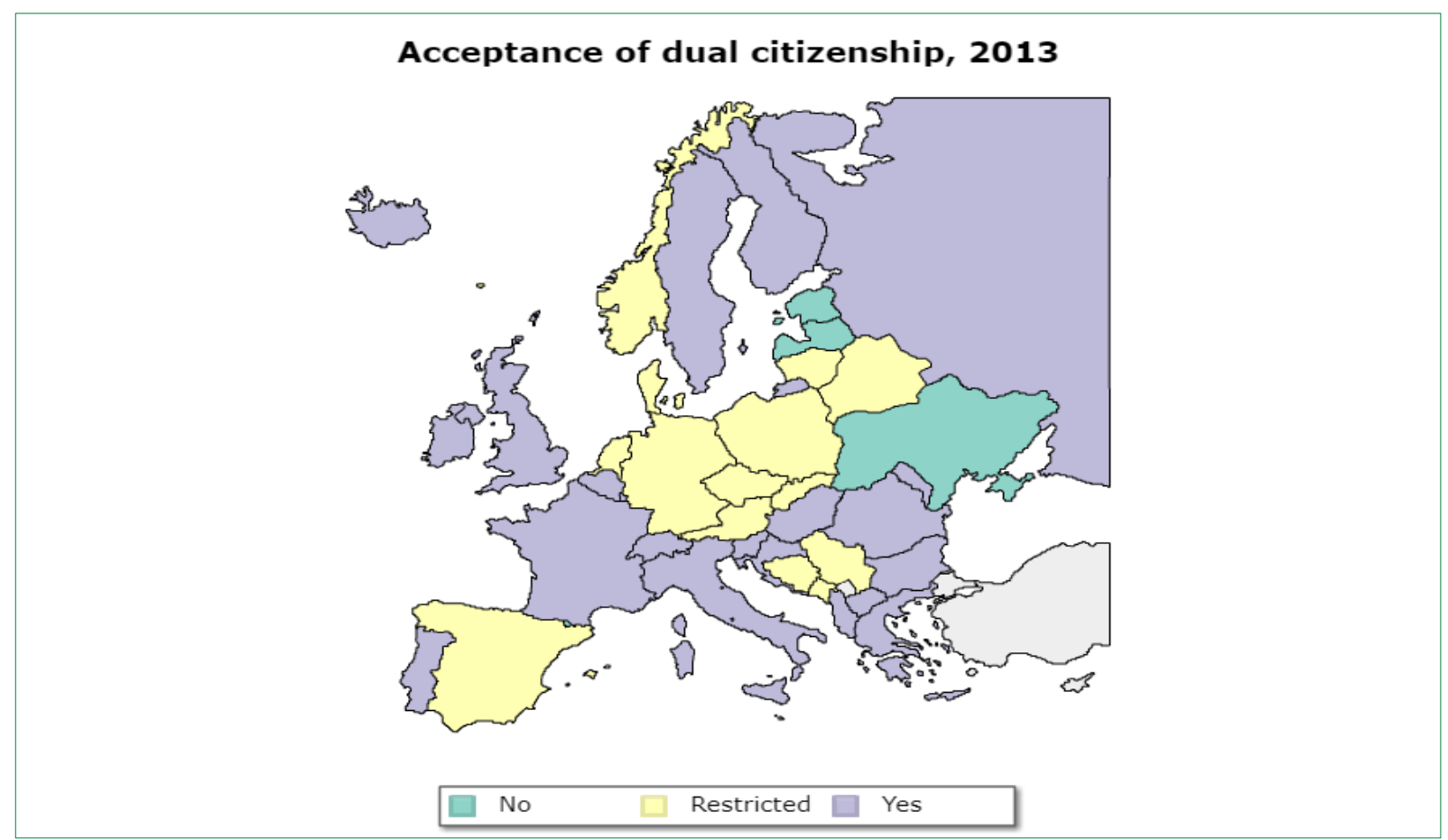

Figure 3. Acceptance of dual citizenship in Europe, 2013

Source: The figures were elaborated by the author based on the database UN DESA World Population Policies Database (https://esa.un.org/PopPolicy/about_database.aspx, accessed 10.05.2019)

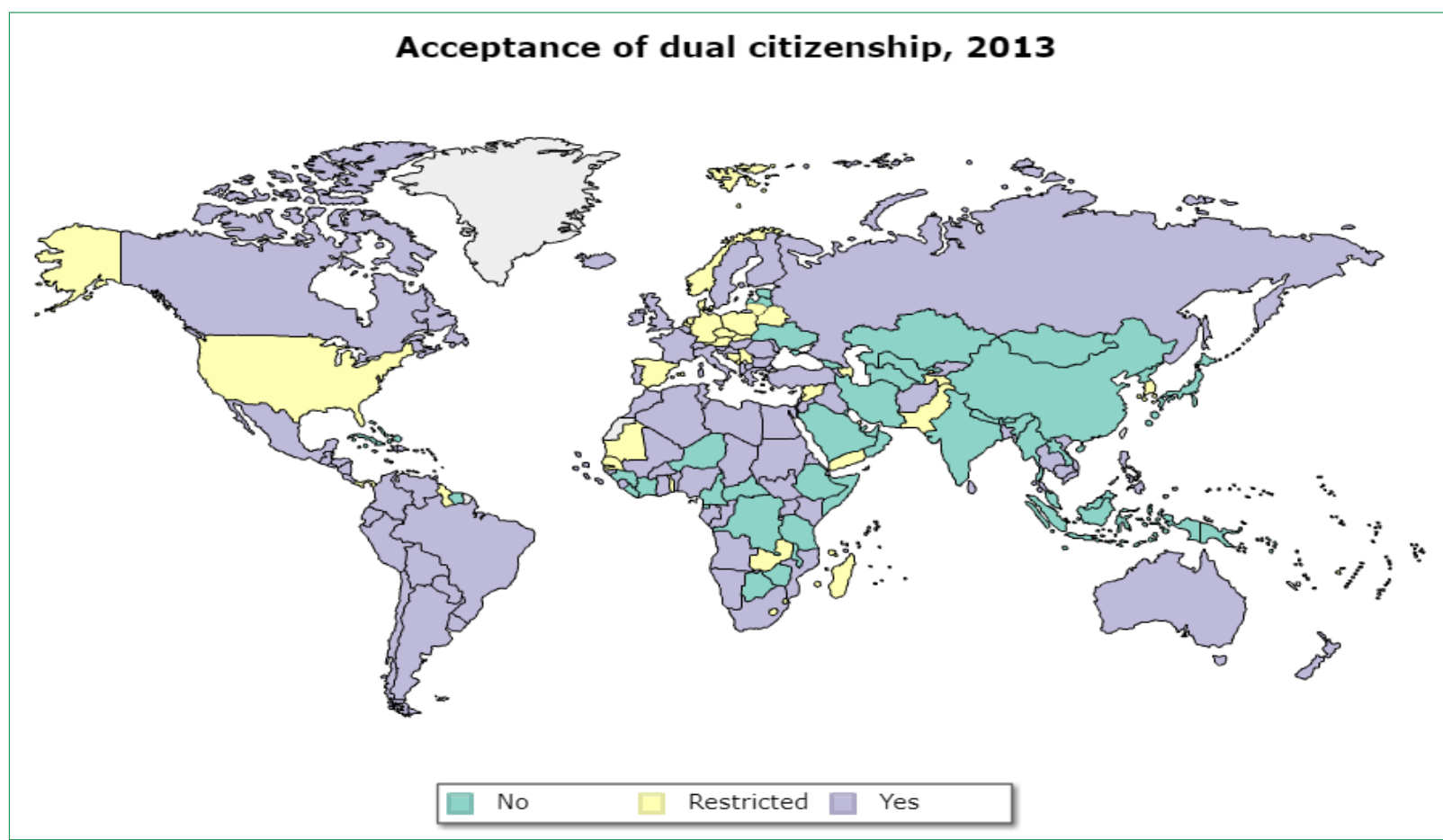

Figure 4. Acceptance of dual citizenship in World, 2013

Source: The figures were elaborated by the author based on the database UN DESA World Population Policies Database (https://esa.un.org/PopPolicy/about_database.aspx, accessed 10.05.2019)

Trends in Moldovan immigrant's access to foreign citizenship Acquiring the citizenship of another country by the citizens from Moldova became possible after 2002 when the Law was amended for this purpose. Until 2002, the Constitution limited the possibility to 
hold other citizenship without losing Moldovan citizenship, except in the cases provided by international agreements to which the Republic of Moldova is a party. Despite some public discussions about possible negotiations for a bilateral agreement on dual citizenship with Romania, Moldova has not signed such treaties (16, GASCA, V., 2012). The effect of the promoted policies is seen in the Figure 5 and Tabel 1, which shows the increased access to foreign citizenship since 2002.

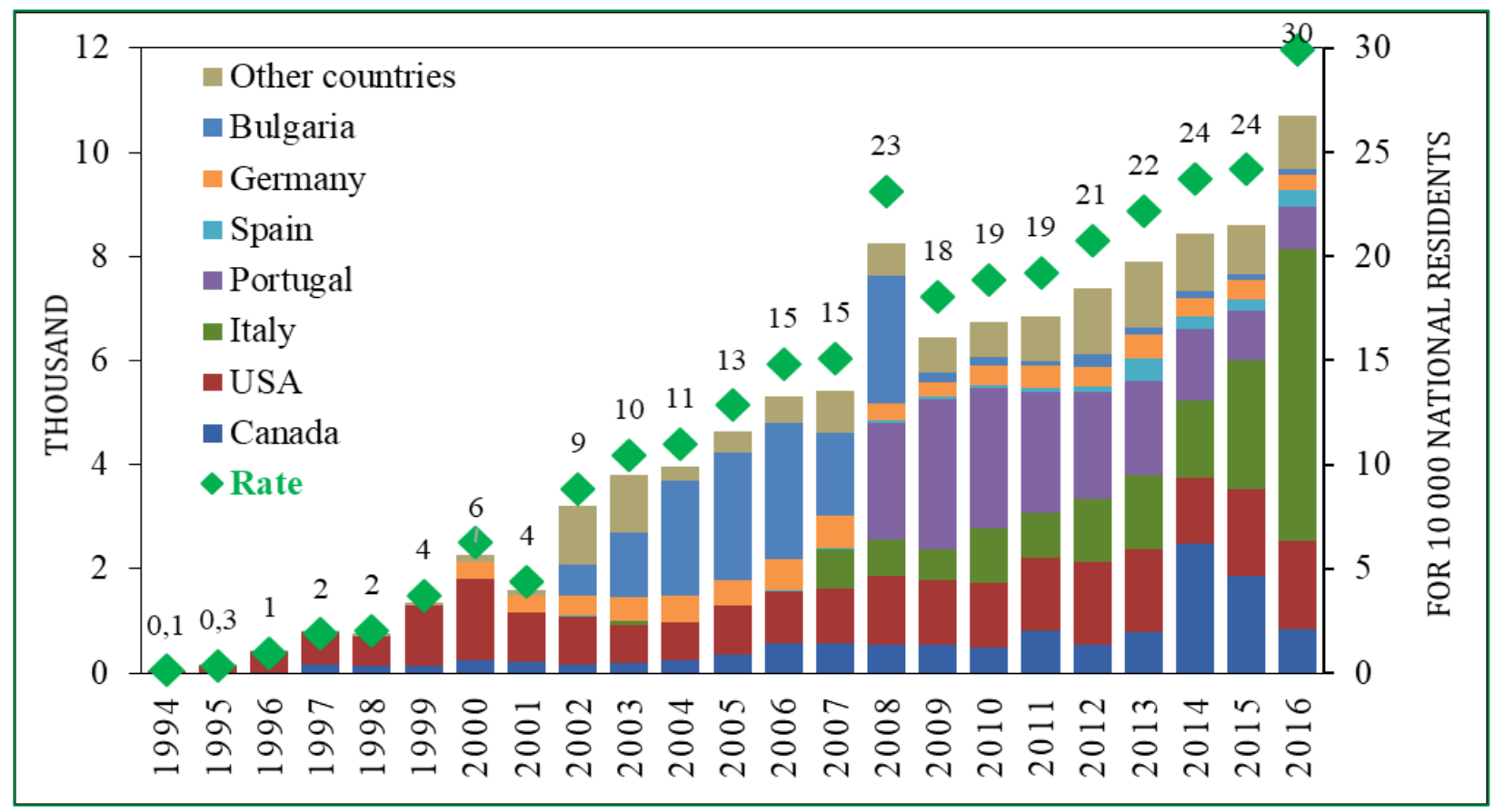

Figure 5. Acquisition of foreign citizenship by Moldovan citizens in 1994-2016 period Source: Author's estimates based on OECD International migration database, Eurostat and National Bureau of Statistics data.

Note: The rate is represented on the left axis.

Table 1

Acquisition of foreign citizenship by Moldovan citizens in selected period and countries (thousand and \%)

\begin{tabular}{|l|c|c|c|c|c|c|c|c|}
\hline \multirow{2}{*}{$\begin{array}{c}\text { Acquisition of } \\
\text { nationality by } \\
\text { country }\end{array}$} & \multicolumn{5}{|c|}{ thousand } & \multicolumn{5}{c|}{$\%$} \\
\cline { 2 - 10 } & $1994-2001$ & $2002-2008$ & $2009-2016$ & $1994-2016$ & $1994-2001$ & $2002-2008$ & $2009-2016$ & $1994-2016$ \\
\hline USA & 5,4 & 6,7 & 11,7 & 23,8 & 73,7 & 19,2 & 18,6 & 22,7 \\
\hline Canada & 0,9 & 2,7 & 8,3 & 11,9 & 12,4 & 7,7 & 13,2 & 11,4 \\
\hline Italy & & 1,6 & 14,7 & 16,2 & & 4,5 & 23,3 & 15,5 \\
\hline Portugal & & 2,2 & 14,9 & 17,1 & & 6,5 & 23,6 & 16,3 \\
\hline Bulgaria & & 13,1 & 1,1 & 14,3 & & 38,0 & 1,8 & 13,6 \\
\hline Germany & 0,6 & 3,3 & 2,9 & 6,9 & 8,5 & 9,6 & 4,6 & 6,5 \\
\hline Spain & & 0,1 & 1,5 & 1,6 & & 0,4 & 2,4 & 1,5 \\
\hline Greece & & 0,1 & 1,1 & 1,1 & & 0,1 & 1,7 & 1,1 \\
\hline United Kingdom & 0,1 & 0,5 & 0,8 & 1,5 & 1,5 & 1,4 & 1,3 & 1,4 \\
\hline France & 0,1 & 0,2 & 0,5 & 0,8 & 1,4 & 0,6 & 0,8 & 0,8 \\
\hline Belgium & & 0,3 & 0,5 & 0,8 & & 0,8 & 0,9 & 0,8 \\
\hline Czech Republic & 0,002 & 0,1 & 0,5 & 0,5 & 0,0 & 0,2 & 0,7 & 0,5 \\
\hline Other countries & 0,2 & 3,8 & 4,4 & 8,3 & 2,6 & 10,9 & 6,9 & 7,9 \\
\hline Total & 7.4 & 34,6 & 63.0 & 105,0 & 100.0 & 100,0 & 100,0 & 100,0 \\
\hline
\end{tabular}

Source: Author's estimates based on OECD International migration database and Eurostat. 
Romania is the country with the most citizenship requests from Moldovan citizens. Unfortunately, there are no official statistical data available to present the exact number of Moldovan citizens who also hold Romanian citizenship, but it is important to know that according to the Romanian Citizenship Law no. 21 of March 1, 1991, the citizens of the Republic of Moldova restore the Romanian citizenship, but do not acquire it. Pursuant to Article 11 of this law, at the regaining of the Romanian citizenship are entitled the persons who acquired it by birth and who lost it for reasons not attributable to them or this citizenship was taken away without their will, as well as their descendents up to the third generation, with possibility of retaining foreign citizenship and establishing their domicile in the country, or keeping it abroad. Thus, the recovery of Romanian citizenship is justified to be done by all persons from the Republic of Moldova who were born and lived in the territory of Romania until 1940 and their descendants up to the third generation.

The regaining of Romanian citizenship plays a very important role in the evolution of migration from Moldova, because it favors the legal migration in UE countries and work migration. The national survey The Barometer of Public Opinion held in April 2007 showed that $1.4 \%$ of the population owned Romanian citizenship, 9.8\% filed the documents for its regaining and 27.0\% intended to submit it. The reasons are free movement in the EU - 18.6\%, legal work in the EU $12.6 \%$, free movement in Romania - 4.7\%, identity and belonging to the Romanian people - $2.5 \%$. However, the massive phenomenon of regaining the Romanian citizenship cannot be considered and analyzed as an ordinary naturalization, since the method by which it is obtained refers to descendant born abroad.

As mentioned, there is no official and transparent source that systematically presents the situation regarding the regaining of Romanian citizenship by Moldovan citizens. Some statistical data are presented periodically in the media. In 2013, the Sorros Foundation Romania estimated at least 400 thousand Moldovan citizens who received Romanian passports during the period 19912012. Subsequently, the Romanian National Authority Citizenship announced that between 2002 and March 2018 Romanian citizenship was regained by about 521 thousand citizens from Moldova. In 2015-2017, about 175 thousand Romanian citizenships were conferred to citizens from Moldova (in 2015 - 45.5 thousand, in 2016 - 61.2 thousand, and in 2017 - 68.6 thousand).

Another specific situation is the acquisition of the citizenship of the Russian Federation by the Moldovan people. Since the break-up of the USSR, in Russia there have been adopted two important legislative acts on citizenship: between 1992-2002 it was in force the law adopted until the break-up of the Soviet bloc, and from 2002 the new law of citizenship was adopted. Russian experts evaluated the law promulgated in the USSR as extremely libertarian, with the procedure of acquiring citizenship very simplified and greatly favoring the inhabitants of the former Soviet countries (8, ČÛINOVSKIH, O.S., 2018), the people in these countries were enough between 3 months and 1.5 years to become Russian citizens.

In order to acquire Russian citizenship, it is imperative that foreigners turn 18 years old, to live uninterruptedly on the territory of the country for 5 years, to speak Russian, to have a legitimate source of livelihood and take an oath of respect for the Constitution of the Russian Federation. At the same time, the legislation also provides for the acquisition of citizenship in a simplified procedure for certain categories of applicants. In the case of the Moldovan population, the procedure for acquiring citizenship is simplified if in the past the applicant has held the citizenship of the USSR, as well as if they participated in the Program for support of voluntary resettlement to Russia of compatriots who live abroad, and has his / her residence in Russia. The data showed that $3.7 \%$ of the naturalized immigrants in Russia are citizens of the Republic of Moldova (8, ČÛDINOVSKIH, O.S., 2018).

At the same time, it is possible for the applicants to obtain citizenship through the foreign institutions of the Russian Federation (these are usually the consulates, embassies), while they are in the territory of the country of residence. This path was best accessed by the population on the left side of the Dniester (8, ČUDINOVSKIH, O.S., 2018). According to the data, over 400 thousand Moldovan citizens (including from Transnistria) acquired the Russian citizenship between 1992 and 2017 (Table 2). 
Persons from Moldova admitted to the Russian citizenship

\begin{tabular}{|c|c|c|c|c|c|c|c|c|c|c|c|}
\hline \multicolumn{3}{|c|}{$\begin{array}{c}\text { Ministry of the Interior/ Federal } \\
\text { Migration Service }\end{array}$} & \multicolumn{4}{|c|}{ Foreign institutions } & \multicolumn{4}{c|}{ Total } \\
\hline Year & Thousand & Year & Thousand & Year & Thousand & Year & Thousand & Year & Thousand & Year & Thousand \\
\hline 1992 & 0,02 & 2005 & 13,7 & 1992 & - & 2005 & 7,7 & 1992 & 0,02 & 2005 & 21,4 \\
\hline 1993 & 0,2 & 2006 & 12,8 & 1993 & - & 2006 & 20,2 & 1993 & 0,2 & 2006 & 33 \\
\hline 1994 & 3,1 & 2007 & 13,9 & 1994 & - & 2007 & 34,8 & 1994 & 3,1 & 2007 & 48,7 \\
\hline 1995 & 8,6 & 2008 & 15,8 & 1995 & - & 2008 & 19,7 & 1995 & 8,6 & 2008 & 35,5 \\
\hline 1996 & 7,7 & 2009 & 20,4 & 1996 & - & 2009 & 21,9 & 1996 & 7,7 & 2009 & 42,3 \\
\hline 1997 & 7,4 & 2010 & 2 & 1997 & - & 2010 & 12,8 & 1997 & 7,4 & 2010 & 14,8 \\
\hline 1998 & 7,1 & 2011 & 2,8 & 1998 & - & 2011 & 9,4 & 1998 & 7,1 & 2011 & 12,2 \\
\hline 1999 & 5,6 & 2012 & 5,3 & 1999 & - & 2012 & 3,7 & 1999 & 5,6 & 2012 & 9 \\
\hline 2000 & 7,1 & 2013 & 12,5 & 2000 & - & 2013 & 4,6 & 2000 & 7,1 & 2013 & 17,1 \\
\hline 2001 & 9 & 2014 & 13,7 & 2001 & - & 2014 & 5,3 & 2001 & 9 & 2014 & 19 \\
\hline 2002 & 6,7 & 2015 & 16,8 & 2002 & - & 2015 & 10,4 & 2002 & 6,7 & 2015 & 27,2 \\
\hline 2003 & 0,4 & 2016 & 23 & 2003 & 1,1 & 2016 & 15,4 & 2003 & 1,5 & 2016 & 38,4 \\
\hline 2004 & 7,3 & 2017 & 29 & 2004 & 5,3 & 2017 & 14,2 & 2004 & 12,6 & 2017 & 43,2 \\
\hline \multicolumn{3}{|c|}{ Total } & $\mathbf{2 5 1 , 9 2}$ & \multicolumn{3}{|c|}{ Total } & $\mathbf{1 8 6 , 5}$ & & Total & $\mathbf{4 3 8 , 4 2}$ \\
\hline
\end{tabular}

Source: the Table was elaborated by the author based on the data presented by Chudinovskikh 2018.

USA and Canada offered citizenship to immigrants born in Moldova with a higher frequency even if the intensity of migration in these countries is lower compared to other countries, for example Italy, Portugal and Germany. Most likely, the answer in this situation is the relatively simple naturalization process among international standards in both Canada and the USA. To become eligible for citizenship, a person must be 18 years old and 5 years of continuous residence in the USA and 3 years (of the last 4 years) in Canada (23, PICOT, G., HOU, F., 2011). Other important conditions are knowledge of English (or French for Canada), knowledge of history and institutions, participation and oath taking, loyalty to the state, lack of criminal record in Canada. At the same time, the children of immigrants born in the US or Canada automatically obtain the citizenship of the respective countries.

The number of naturalized persons during the whole period analyzed is estimated at almost 24 thousand in the USA and 12 thousand in Canada. Of the total number of naturalized migrants in the period 2002-2016, about 19\% occurred in the US and 8-13\% in Canada (Table 2).

There are known several periods when immigrants to the US were naturalized in greater numbers, namely the years 1999-2000, 2012-2013 and the last years 2015-2016. The majority of immigrants who acquired citizenship in 1999-2000 arrived between 1991 and 1994 (86\% and 91\%, respectively).

This increase was due, on the one hand, to improving the conditions for processing applications, and on the other hand to the 1996 legislative changes (PRWORA), which canceled many privileges for non-US citizens, which encouraged immigrants to gain citizenship (14, ENCHAUTEQUI, M.E., GIANNARELLI, L., 2015; 5, BLOEMRAAD, I., 2006). In the other two periods, the increase of naturalization is closely related to the increase of the migration flows. In 2005-2006 there were two large flows of immigrants of about 3.5 and 3.0 thousand people, the majority being refugees and asylum seekers (29, TABAC T., 2015), which caused the increase of naturalization in 2012-2013. This tendency can be followed permanently in the USA, the increase of the migratory flows leads respectively to the growth of the naturalized persons in the following years. Based on these findings, we can consider that the migrants from the Republic of Moldova have motivation and desire to stay in the USA, and the citizenship is an opportunity in this regard.

In the case of Canada, the trend of naturalization has been stable throughout the years except for 2014 and 2015, when the number of naturalizations increased by $220 \%$ and $140 \%$, respectively. We can assume that the situation occurred due to the intensification of the migration flows in 2009 and 2010 by $36 \%$ and $76 \%$, respectively. However, during this period the processing fee has been changed 
and the cost for citizenship has increased significantly, and when a new amendment comes into effect, there may be an increase in demand before the new requirement comes into effect, and a decline after that, as shown in the data presented below.

Southern Europe: Italy, Portugal, Spain and Greece. To become eligible for citizenship in these countries it takes a period of residence of 6-7 years for Portugal and Greece and ten years of residence in Italy and Spain (in Italy the period is reduced to four years for citizens from EU countries). Other conditions: sufficient knowledge of the national language (for Portugal), as well as the culture and history of the country (for Greece), no criminal records of certain crimes (Italy, Portugal and Greece), stable and sufficient income (Italy and Greece), to prove adequate social integration (Portugal and Spain). For Spain it is especially important the oath of loyalty to the King and obedience to the Constitution and renouncing to the citizenship of the country of origin. All these countries, except Italy, ask persons applying for naturalization to demonstrate that they are integrated into society based on an integration test (24, PASCOUAU, Y., BRUYCKER, P., 2011).

The naturalization of immigrants in Southern European countries began in the second half of the 20th century due to the fact that immigration to these territories is a relatively new phenomenon (27, Tabac T., 2018) considering that the Republic of Moldova has gained independence from the Soviet bloc recently. At the same time, an important factor in this situation is the public policies that regulate more restrictive naturalization procedures, compared to the countries analyzed above (in Italy and Spain it takes 10 years of legal residence while in Spain it is also required to renounce to the previous citizenship). From the data we can see that immigrants started to acquire citizenship in Portugal first, the period of intensive naturalization being observed between 2008-2013. The naturalization of immigrants in Italy increased with 2012, which means ten years from Law No.189 of July 30, 2002 (Bossi-Fini Law), famous for the amnesty offered to illegal immigrants. From the data it is also observed the increase of naturalization up to 5.6 thousand in 2016, a highly significant increase in our case. For the whole analyzed period, 16.2 thousand immigrants acquired the Italian citizenship and 17.1 thousand the Portuguese citizenship. The citizenship of Spain and Greece was acquired by a very small number of immigrants, 1.6 thousand and 1.1 thousand, respectively, because in Spain the conditions are harsher, whereas in Greece the immigration was the lowest.

Western Europe: Germany, Belgium, France and the UK. In the recent years, an intensification of the migration flows from Moldova to this region is registered, largely due to the increase of the number of Romanian citizens (27, Tabac T., 2018). From this reason, we consider necessary an analysis of the current state regarding the acquisition of the citizenship of these countries.

To become a citizen in Belgium, France and the UK it is required a minimum of five years of continuous residence, while in Germany - eight years (ten years until 2000). Other specific requirements besides the knowledge of the language of the country, socio-economic integration, lack of criminal convictions, it is necessary to know the constitutional rights and duties in the case of France, and the intention to have the main domicile in the case of the UK. The conditions for acquiring the citizenship of Germany are tougher than in the other countries. Besides the fact that the knowledge of the German legal system and the demonstrated ability to support oneself and family without requesting for unemployment benefits are required, a mandatory condition is to give up to the citizenship of the country of origin. However, the largest number of immigrants from Moldova to Western Europe have acquired German citizenship. Between 1994-2016, 6.9 thousand immigrants have acquired German citizenship, 1.5 thousand UK citizenship and 0.8 thousand each - French and Belgian citizenship. Immigrants to Germany also gain citizenship through cultural-ethnic affinity. That is, German ethnic immigrants from Eastern Europe who, with the break-up of the Soviet bloc, settled in Germany on the basis of a special certificate have the opportunity to automatically acquire citizenship through descents. However, renouncing another citizenship is required. According to Statistisches Bundesamt, about $90 \%$ of immigrants obtain citizenship through naturalization, the proportion of naturalization being estimated at 3-5\% of the stock of immigrants from Moldova (28, Tabac T., 2017).

Other countries of naturalization in the analyzed period are Bulgaria (14.3 thousand), Ireland (2.3 thousand), Turkey (2.1 thousand), Czech Republic ( 0.5 thousand), Netherlands and Australia (each 0.4 thousand). In Bulgaria it is registered the largest number due to the simplified rules for offering citizenship since 2001, the mode of acquisition of citizenship is "by origin" and it implies the 
demonstration of ethno-cultural affinity with the Bulgarian nation. Although Moldovan emigration to Bulgaria has not been registered, the number of naturalized persons is close to that of Portugal and Italy. Many have acquired Bulgarian citizenship for emigration and legal work in EU countries.

To become a citizen in the Czech Republic it is necessary to renounce the citizenship of another country, which motivates the Moldovan immigrants to access Czech citizenship. In this case, we can support the negative influence of policies because the flows of immigrants to the Czech Republic have always been at the level of flows in Portugal (27, Tabac T., 2018). The situation is also specific in the Netherlands because it is required to renounce the citizenship of another country if it exists, but the number of immigrants in this country is not significant either.

The conditions of citizenship in Ireland and Australia are relatively simple. There are required from two years (in Australia) to five years of residence (in Ireland), expressed intention to remain in the country, good character and loyalty to the state.

Insufficient statistical data does not allow us to mention the exact number of people who obtained citizenship in Turkey during the analyzed period, only data for 2002 and 2003 shows about 970 and 900 , respectively. Such growth certainly represents changes in the level of policies promoted.

\section{CONCLUSIONS}

In the context of the ones mentioned in this paper we conclude that at present, a significant number of Moldovan citizens also possess the citizenship of another state. The anticipated estimates that we have at the moment allow us to consider that their number can be 1 million people, with some variations. Reporting to the stable population of the country, this number represents $1 / 3$ of the total. Of course, the policies promoted by the other states had a great impact and for some countries it was not necessary for the citizen to be a classical immigrant established and integrated in the society. The case of Romania, but also of Bulgaria, is quite specific in this context because the acquisition of citizenship is made in line with ethnic and cultural origins with the respective countries. At the same time, the naturalization of immigrants in the Russian Federation was favored on the one hand by facilitated policies for the former USSR, and on the other hand by the socio-cultural similarities between the populations of these societies (knowledge of the Russian language, similar values and so on).

About a classic process of naturalization in which an immigrant must demonstrate eligibility for citizenship through socio-economic integration we can speak in the context of European and overseas countries. Here, the impact of policies promoted by the countries of destination is observed too, and in this respect Canada and USA differ from most EU countries by less austere naturalization policies. We consider that the naturalization of immigrants in the EU is low compared to the annual flows that go here and the stocks formed over the years. Immigrants from Moldova have demonstrated that they can successfully integrate socially and economically in all emigration countries and European countries are not an exception. We also want to emphasize the importance of tolerance towards dual citizenship (which exists both in the Republic of Moldova and in most of the host countries) as a determining factor in accessing foreign citizenship by Moldovan immigrants.

Acquiring the citizenship of developed countries offers various benefits to immigrants from Moldova, therefore the proportion of naturalizations is constantly increasing. The most important benefit is considered the mobility without barriers at international level, or in the case of the Republic of Moldova there are travel restrictions in the most countries of the world. The citizenship of a European country favors not only the visits, but also the employment in any of the EU countries, insurance,social and legal protection in the country of destination, as well as the opportunity of migration for settlement. These benefits are important for Moldovan migrants considering the poor socioeconomic situation and political instability in the country.

To our best knowledge, this is the first study that addresses the acquisition of foreign citizenship by Moldovan immigrants and indicates the need to develop in perspective the analyzes on the economic and social benefits of naturalization. It is also important and useful to know the extent to which naturalization can increase among immigrants eligible for naturalization. The longer the immigrants are in the host country, the more the opportunity for naturalization increases. Equally important is the knowledge of the socio-economic characteristics of naturalisers. 


\section{REFERENCES}

1. BAUBOCK, R. et al. Migration and Citizenship: legal status, rights and political participation. Amsterdam: Amsterdam University Press, 2006. 128 p. ISBN 9789053568880.

2. BEVELANDER, P. Naturalisation and Social Inclusion. Naturalisation: A Passport for the Better Integration of Immigrants? Paris: OECD, 2010, pp. 237-250. [Accesat 29.03.2019]. Disponibil: doi.org/10.1787/9789264099104-en

3. BEVELANDER, P., DEVORETZ, D.J. The Economics of Citizenship. Malmo: Malmo University, 2008. ISBN 978-91-7104-079-4.

4. BEVELANDER, P., VEENMAN, J. Naturalization and Immigrants' Employment Integration in the Netherlands. In: Journal of International Migration and Integration. 2006, vol. 7 (3), pp. 327-349. ISSN 1874-6365. [Accesat 15.04.2019]. Disponibil: doi.org/10.1007/s12134-006-1016-y

5. BLOEMRAAD, I. Becoming a Citizen in the United States and Canada: Structured Mobilization and Immigrant Political Incorporation. In: Social Forces. 2006, vol. 85 (2), pp. 667-695. ISSN 1534-7605. [Accesat 19.06.2019]. Disponibil: doi:10.1353/sof.2007.0002

6. BRATSBERG, B., RAGAN, Jr., J.F., NASIR, Z.M. The effect of naturalization on wage growth: A panel study of young male immigrants. In: Journal of Labor Economics. 2002, vol. 20 (3), pp. 569-597. ISSN 1537-5307. [Accesat 29.03.2019]. Disponibil: https://www.journals.uchicago.edu/doi/abs/10.1086/339616

7. CHISWICK, B.R., MILLER, P.W. Citizenship in the United States: The Role of Immigrant Characteristics and Country of Origin. IZA Discussion Paper. 2008, no. 3596. [Accesat 12.05.2019]. Disponibil: https://www.emerald.com/insight/content/doi/10.1108/S01479121(2009)0000029007/full/html

8. ČÛDINOVSKIH, O.S. Statistika priobreteniâ graždanstva kak otraženie osobenostej migracionoj politiki Rossii. V: Voprosy Statistiki. 2018, № 25 (9), ss. 3-26. ISSN 2313-6383.

9. DELEU, Ecaterina. Generații secunde de migrație: cazul Republicii Moldova. Institutul de Cercetări Juridice și Politice al Academiei de Științe a Moldovei. Chișinău, 2017. 344 p. ISBN 978-9975-53-777-3.

10.DEROOIJ, E.A. Patterns of Immigrant Political Participation: Explaining Differences in Types of Political Participation between Immigrants and the Majority Population in Western Europe. In: European Sociological Review. 2012, vol. 28 (4), pp. 455-481. ISSN 1468-2672. [Accesat 29.03.2019]. Disponibil: https://doi.org/10.1093/esr/jcr010

11.DEVORETZ, D.J., PIVNENKO, S. The Economic Determinants and Consequences of Canadian Citizenship Ascension. In: The Economics of Citizenship. Malmo: Malmo University, 2008, pp. 23-61. ISBN 978-91-7104-079-4. [Accesat 12.05.2019]. Disponibil: https://pdfs.semanticscholar.org/8dff/d7931b3bd120a13e1b61189096e6d27ec046.pdf

12.DEVORETZ, D.J., PIVNENKO, S. The Economic Causes and Consequences of Canadian Citizenship. In: Journal of International Migration and Integration. 2005, vol. 6 (3-4), pp. 435-468. ISSN 1874-6365. [Accesat 11.03.2019]. Disponibil: https://link.springer.com/article/10.1007/s12134-005-1021-6

13.European Demographic Data Sheet. 2018. [Accesat 15.07.2019]. Disponibil: http://www.populationeurope.org/

14.ENCHAUTEQUI, M.E., GIANNARELLI, L. The Economic Impact of Naturalization on Immigrants and Cities. Urban Institute. 2015, december. 38 p. [Accesat 11.03.2019]. Disponibil: https://www.urban.org/sites/default/files/publication/76241/2000549-The-Economic-Impact-ofNaturalization-on-Immigrants-and-Cities.pdf

15.GAGAUZ, O., STRATAN, A., BUCIUCEANU-VRABIE, M., PENINA, O., CIUBOTARU, V., CHEIANUA-ANDREI, D. Population Situation Analysis in the Republic of Moldova. Chișinău, 2016. 174 p. [Accesat 11.03.2019]. Disponibil: https://moldova.unfpa.org/sites/default/files/pub-pdf/PSA_engleza.pdf

16.GASCA, Viorelia. Country report: Moldova. EUDO Citizenship Observatory. 2012, november. [Accesat 21.06.2019]. Disponibil: http://eudo-citizenship.eu/docs/CountryReports/Moldova.pdf

17.GUIMEZANES, N. The current status of nationality law. In: Naturalisation: A Passport for the Better Integration of Immigrants? Paris: OECD, 2011, pp. 65-95. [Accesat 11.03.2019]. Disponibil: https://www.oecd-ilibrary.org/docserver/9789264099104-

en.pdf?expires=1577353393\&id=id\&accname=oid034021\&checksum=EFF3183DCDCF29F7611933 5DCFF65B5B

18.HAINMUELLER, J., LAWRENCE, D. et al. A randomized controlled design reveals barriers to citizenship for low-income immigrants. In: PNAS. 2018, vol. 115 (5), pp. 939-944. [Accesat 11.03.2019]. Disponibil: doi.org/10.1073/pnas.1714254115 
19.JONES-CORREA, M. Under Two Flags: Dual Nationality in Latin America and Its Consequences for Naturalisation in the United States. In: The International Migration Review. 2001, vol. 35 (4), pp. 997 1029. [Accesat 11.03.2019]. Disponibil: doi.org/10.1111/j.1747-7379.2001.tb00050.x

20.KERNO, I.S. Nationality, including Statelessness - Analysis of Changes in Nationality Legislation of States since 1930. United Nations. 1957. [Accesat 24.05.2019]. Disponibil: http://legal.un.org/ilc/documentation/english/a_cn4_67.pdf

21.LIEBIG, T., VON HAAREN, F. Citizenship and the Socioeconomic Integration of Immigrants and Their Children. In: Naturalisation: A Passport for the Better Integration of Immigrants? Paris: OECD, 2011, pp. 23-57. [Accesat 24.05.2019]. Disponibil: doi.org/10.1787/9789264099104-en

22.MAZZOLARI, F. Dual Citizenship Rights: Do They Make More and Richer Citizens? In: Demography. 2009, vol. 46 (1), pp. 169-191. ISSN 1533-7790. [Accesat 24.05.2019]. Disponibil: doi.org/10.1353/dem.0.0038

23.PICOT, G., HOU, F. Citizenship Acquisition in Canada and the United States: Determinants and Economic Benefit. In: Naturalisation: A Passport for the Better Integration of Immigrants? Paris: OECD, 2011, pp. 153-182. [Accesat 24.05.2019]. Disponibil: doi.org/10.1787/9789264099104-en

24.PASCOUAU, Y., BRUYCKER, P. Integration and Acces to Nnationality in EU Member Countries. In: Naturalisation: A Passport for the Better Integration of Immigrants? Paris: OECD, 2011, pp. 251-259. [Accesat 14.07.2019]. Disponibil: doi.org/10.1787/9789264099104-en

25.SCOTT, J.B. Nationality: Jus Soli or Jus Sanguinis. In: The American Journal of International Law. 1930, vol. 24 (1), pp. 58-64. [Accesat 14.07.2019]. Disponibil: https://www.jstor.org/stable/2189299?seq=1

26.STEINHARDT, M.F., WEDEMEIER, J. The Labor Market Performance of Naturalized Immigrants in Switzerland - New Findings from the Swiss Labor Force Survey. In: Journal of International Migration and Integration. 2011, vol. 13, pp. 223-242. ISSN 1874-6365. [Accesat 14.07.2019]. Disponibil: doi:10.1007/s12134-011-0213-5

27.TABAC, Tatiana. Long-term migration from Republic of Moldova and Romania. In: The Yearbook of the Gh. Zane Institute of Economic Research. 2018, vol. 27, pp. 79-90. [Accesat 14.07.2019]. Disponibil: https://ideas.repec.org/a/zan/ygzier/v27y2018i1p79-90.html

28.TABAC, Tatiana. Migrația populației din Republica Moldova în Germania în anii 1992-2016. In: Creșterea economică în condițiile globalizării: modele de dezvoltare durabilă: conferința internațională științifico-practică. Sesiunea științifică "Dinamica populației și calitatea potențialului uman", 12-13 octombrie 2017. Ediția a XII-a, Chisinau: INCE, 2017, pp. 133-141. ISBN 978-9975-3171-7-7.

29.TABAC, Tatiana. Moldovenii în "Țara visurilor". In: Populație și Dezvoltare: Buletin informativ. Chișinău: CCD, UFPA, 2015, nr. 2, pp. 5-7. [Accesat 14.07.2019]. Disponibil: http://demografie.md/files/files/bi2015.pdf

30.TRAN, K., KUSTEC, S., CHUI, T. Becoming Canadian: Intent, Process and Outcome. In: Canadian Social Trend, Statistics Canada Catalogue. 2005, no. 11-008, 76, pp. 8-13. [Accesat 14.07.2019]. Disponibil: https://www150.statcan.gc.ca/n1/en/pub/11-008-x/11-008-x2004004-eng.pdf?st=Ydhp0u7M

31.VINK, M.P., PROKIC-BREUER, T., DRONKERS, J. Access to Citizenship and the Role of Origin Countries. In: Migrant Integration Between Homeland and Host Society. 2017, vol.1, pp. 201-224. [Accesat 14.07.2019]. Disponibil: doi:10.1007/978-3-319-56176-9_9

32.VINK, M.P., PROKIC-BREUER, T., DRONKERS, J. Immigrant Naturalization in the Context of Institutional Diversity: Policy Matters, but to Whom? In: International Migration. 2013, vol. 51 (5), pp. 1-20. [Accesat 23.07.2019]. Disponibil: doi: 10.1111/imig.12106

33.VINK, M.P., DRONKERS, J. Explaining access to citizenship in Europe: How citizenship policies affect naturalization rates. In: European Union Politics. 2012, vol. 13 (3), pp. 390-412. ISSN 1741-2757. [Accesat 23.07.2019]. Disponibil: doi.org/10.1177/1465116512440510

34.YANG, P.Q. Explaining Immigrant Naturalization. In: The International Migration Review. 1994, vol. 28 (3), pp. 449-477. ISSN 1747-7379. [Accesat 23.07.2019]. Disponibil: doi:10.2307/2546816

\section{ARTICLE HISTORY}

Received 12 November 2019

Accepted 24 December 2019 